\title{
STRATEGI KOMUNIKASI ORANG DENGAN HIV AIDS (ODHA) MENGHADAPI STIGMA MASYARAKAT
}

\author{
Riniwaty Makmur \\ Mahasiswa Program Doktor Ilmu Komunikasi Universitas Padjadjaran \\ Jalan Raya Sumedang Jawa Barat \\ Email:rmakmur@yahoo.com
}

\begin{abstract}
Results of various researches about people with HIV AIDS (ODHA) concluded that in general, stigma happens to ODHA. Stigma has been a basis for discrimination against ODHA and becoming obstacle in many efforts to overcome impact of HIV AIDS. This research uses the qualitative approach and the data was collected through interview, document review, including discussion found in specific websites used by ODHA support group. The research uncovered that ODHA has been stigmatized by a range of group such as family, school, and religious leader. In dealing with stigma, some of ODHAs prefer to keep their status in secret, in order to protect themselves and their family, and some others choose to be straightforward about their condition. The decision on what strategy to take, significantly depends on support they receive from family and their significant others.
\end{abstract}

Keywords: ODHA, HIV AIDS, Stigma, Discrimination

\begin{abstract}
Abstrak
Menurut berbagai penelitian, stigma terhadap ODHA (Orang dengan HIV AIDS) telah umum terjadi. Stigma ini menyebabkan diskriminasi terhadap ODHA dan menjadi kendala dalam upaya-upaya menanggulangi dampak HIV AIDS. Penelitian ini mencoba menggambarkan strategi dan tindakan ODHA menghadapi stigma dalam keseharian mereka. Penelitian ini menggunakan pendekatan kualitatif dengan teknik wawancara mendalam dan telaah dokumen termasuk percakapan dari forum diskusi ODHA di situs kelompok dukungan bagi ODHA. Penelitian ini menemukan bahwa stigma dialami ODHA, dengan pelaku beragam seperti keluarga, sekolah dan pemuka agama. Dalam menghadapi stigma, ada ODHA yang memilih tidak berterus terang untuk melindungi dirinya dan keluarga, dan ada juga yang berterus terang atau apa adanya. Faktor dukungan keluarga dan orang dekat sangat penting dalam pilihan strategi ODHA mengenai kondisinya.
\end{abstract}

Kata kunci: ODHA, HIV AIDS, Stigma, Diskriminasi

\section{PENDAHULUAN}

Kasus HIV-AIDS di Indonesia terus bertambah. Laporan dari
Departemen Kesehatan mengungkapkan bahwa hingga akhir 2015, terdapat kumulatif 77,112 orang penderita 
Riniwaty Makmur, Strategi Komunikasi Orang Dengan Hiv Aids (Odha) Menghadapi Stigma..

AIDS, dan 191,073 orang penderita $\mathrm{HIV}^{1}$ di seluruh Indonesia, atau terjadi kenaikan sekitar $16 \%$ dari 2014 (Infodatin, 2014).

HIV

atau Human

Immunodeficiency Virus adalah virus yang menyerang sel darah putih di dalam tubuh (limfosit) yang mengakibatkan turunnya kekebalan tubuh manusia. Orang yang dalam darahnya terdapat virus HIV bisa tampak sehat dan belum membutuhkan pengobatan. Namun, orang tersebut dapat menularkan virusnya kepada orang lain bila melakukan hubungan seks, memakai alat suntik yang telah tercemar HIV terutama jika memakai alat suntik bersama di kalangan pengguna narkoba suntik (penasun). Selain itu, HIV juga bisa ditularkan melalui beberapa cara seperti transfusi darah dari darah yang sudah tercemar HIV, ibu HIV positif selama masa kehamilan, waktu persalinan dan/ atau waktu menyusui.

Status terinfeksi HIV hanya dapat diketahui setelah mengikuti test HIV yang disertai konseling atau yang disebut dengan VCT (Voluntary Counseling and Testing). Tes HIV biasanya bersifat sukarela dan rahasia, dilakukan melalui tes darah untuk memastikan adanya antibodi HIV di dalam sampel darah. Sebelum melakukan tes HIV, akan diadakan konseling untuk mengetahui tingkat risiko infeksi dari perilaku selama ini

\footnotetext{
${ }^{1}$ Sumber data dari dari Statistik kasus HIV AIDS di Indonesia sampai dengan Desember 2015, publikasi Ditjen PP (Pengendalian Penyakit) dan PL (Penyehatan Lingkungan) Kemenkes RI
}

dan bagaimana nantinya harus bersikap setelah mengetahui hasil tes HIV. Untuk tes cepat dapat juga digunakan tes usapan selaput lendir mulut (Oraquick).

AIDS atau Acquired Immune Deficiency Syndrome adalah sekumpulan gejala penyakit yang timbul karena turunnya kekebalan tubuh. AIDS disebabkan oleh infeksi HIV. Akibat menurunnya kekebalan tubuh pada seseorang maka orang tersebut sangat mudah terkena penyakit seperti TBC, kandidiasis, berbagai radang pada kulit, paru, saluran pencernaan, otak dan kanker. AIDS dapat dicegah dengan pengobatan antiretroviral atau ARV. Pengobatan ARV menekan laju perkembangan virus HIV di dalam tubuh sehingga orang dengan infeksi HIV dapat kembali "sehat" atau "bebas gejala.' Namun virus HIV masih ada di dalam tubuhnya dan tetap bisa menularkan pada orang lain ${ }^{2}$.

Tahun 2014, UNAID (United Nations Programme on HIV/AIDS) mencanangkan program "Fast Track" untuk mengakhiri epidemi AIDS pada $2030^{3}$. Program ini mengusulkan akselerasi cepat dan masif bagi layanan pencegahan dan pengobatan HIV yang berpusat pada manusia untuk mengakhiri epidemi AIDS pada 2030. Jakarta termasuk salah satu kota yang berpartisipasi dalam program fast track ini.

\footnotetext{
${ }^{2}$ Sumber: Komisi Penanggulangan Aids (KPA) pada situs:

http://www.aidsindonesia.or.id/contents/37/78/I nfo-HIV-dan-AIDS\#sthash.je6iI6qi.dpuf

${ }^{3}$ Sumber:

http://www.unaids.org/en/resources/presscentre/pressrelea seandstatementarchive/2014/september/20140925_pr_fas t_track/
} 
Akses terhadap pengobatan HIV hanyalah salah satu dari masalah yang dihadapi Orang-orang dengan HIV AIDS (ODHA). Masalah lain yang cukup signifikan adalah stigma ${ }^{4}$ dan diskriminasi ${ }^{5}$ dari keluarga, kenalan dan anggota masyarakat. Ketakutan akan stigma dan diskriminasi menjadi salah satu penyebab utama banyak orang enggan mengikuti VCT. Stigma dan diskriminasi ini pula yang masih banyak dialami oleh ODHA (Sosodoro et al., 2009; Butt et al., 2010; Hermawati, 2011; Harapan et al., 2013; UNAIDS, 2016). Tahun 2011 misalnya, dunia pendidikan dihebohkan oleh penolakan sebuah sekolah terhadap seorang anak yang sebelumnya telah diterima di sekolah itu. Pasalnya, dalam sesi wawancara dengan orang tua si anak, orang tuanya mengakui bahwa si ayah adalah seorang penderita HIV. Sekolah beralasan tindakannya menolak anak itu atas desakan oleh orang tua-orang tua lain yang takut anak mereka ketularan. Padahal anak yang ditolak itu sehat walafiat, alias sama sekali tidak menderita HIV apalagi AIDS ${ }^{6}$.

Pada Januari 2016, ABC News, media daring dari Australia mengungkapkan keberadaan sekitar

\footnotetext{
${ }^{4}$ Stigma menurut Kamus Besar Bahasa Indonesia $(\mathrm{KBBI})$ versi daring adalah ciri negatif yang menempel pada pribadi seseorang karena pengaruh lingkungannya, atau tanda.

${ }^{5}$ Diskriminasi menurut KBBI versi daringa berarti pembedaan perlakuan terhadap sesama warga negara (berdasarkan warna kulit, golongan, suku, ekonomi, agama, dan sebagainya).

${ }^{6}$ Sumber:

https://m.tempo.co/read/news/2011/12/05/08337 0012/kasus-orang-tua-odha-yayasan-don-boscominta-maaf dan

http://www.bbc.com/indonesia/berita_indonesia /2011/12/111205_aidsdonbosco.shtml
}

sembilan orang anak yatim piatu ODHA di Kota Solo yang ditolak oleh komunitas di sekitar lokasi panti asuhan mereka. Para relawan terpaksa mencarikan anak-anak itu tempat penampungan sementara. Kendati para dokter telah berusaha menjelaskan bahwa HIV AIDS tidak menular melalui kontak dengan penderitanya, anggota masyarakat tidak mau tahu. Pekerja sosial yang mendampingi anakanak tidak bersalah itu mengatakan bahwa selain komunitas takut terinfeksi HIV, ada stigma dan diskriminasi mengenai asal dari penyakit HIV AIDS $^{7}$. Anak-anak tersebut diketahui mendapatkan HIV dari ibu mereka. Setelah ibunya meninggal, keluarga menolak untuk merawat mereka.

Laporan mutakhir mengenai AIDS dari UNAIDS tahun 2016, mengungkapkan bahwa ketidakpedulian dan ketidakmengertian terus terjadi dan merusak upaya-upaya untuk mengakhiri AIDS. Pada kasus-kasus terburuk, sikap-sikap dan perilaku diskriminasi bahkan difasilitasi oleh kebijakankebijakan dan hukum resmi. Tahun 2016, 72 negara memiliki hukum yang membiarkan kriminalisasi, khususnya terhadap HIV (Unaids, 2016: 10).

Stigma adalah hal pertama yang disebutkan oleh seorang dokter pegiat HIV/AIDS, ketika ditanya mengenai tantangan terbesar yang dihadapinya dalam menjalankan tugasnya di KPA (Komisi Penanggulanan AIDS). KPA adalah lembaga pemerintahan non

\footnotetext{
${ }^{7}$ Sumber: http://www.abc.net.au/news/2016-0108/orphans-rejected-by-indonesian-community-forhaving-hiv/7075360
} 
Riniwaty Makmur, Strategi Komunikasi Orang Dengan Hiv Aids (Odha) Menghadapi Stigma..

struktural yang dibentuk di daerahdaerah dengan tugas melakukan upayaupaya promotif, preventif, kuratif, dan rehabilitatif mengenai HIV AIDS dan penderitanya. Padahal banyak penderita yang mendapatkan HIV karena keadaan yang tidak diduganya, seperti transfusi darah, atau korban dari pasangan yang berisiko, atau anak dari ibu HIV.

Belum meratanya kesadaran/pengetahuan mengenai HIV AIDS, dan stigma terhadap ODHA bisa menjadi kendala dalam upaya mengakhiri epidemi AIDS. Penelitian ini mendeskripsikan keadaan saat ini menyangkut stigma terhadap HIV AIDS dan ODHA, serta bagaimana strategi ODHA dalam menghadapi stigma yang ada di lingkungannya. Berdasarkan paparan tersebut di atas permasalahan penelitian ini dapat dirumuskan sebagai berikut: Bagaimana strategi dan tindakan ODHA (orang dengan HIV AIDS) menghadapi stigma mengenai penyakit mereka?

\section{TINJAUAN PUSTAKA}

Konsep mengenai stigma diperkenalkan oleh Goffman, yang melihat stigma sebagai proses berdasarkan konstruksi indentitas sosial. Orang-orang yang terkait dengan kondisi penstigmaan berpindah dari "normal" menjadi "diskredit" atau secara status sosial "didiskreditkan" (Kleinman dan Hall-Clifford, 2009: 1). Goffman mengatakan Orang-orang yang distigma adalah mereka yang tidak memiliki penerimaan sosial penuh, dan terus menerus berusaha menyesuaikan identitas sosial mereka: orang-orang yang cacat fisik, pasien-pasien kejiwaan, pencandu obat-obatan, prostitusi, dan sebagainya (Crossman, 2016). Terdapat tiga jenis stigma yaitu, stigma karena sifat/ ciri-ciri karakter, keadaan fisik, dan identitas kelompok.

Kecacatan karakter individual dipersepsikan sebagai keinginan yang lemah, dominasi, atau keinginan yang tidak alami, kepercayaan yang kaku, dan ketidakjujuran. Mereka yang masuk ke dalam kategori ini adalah penderita sakit mental, narapidana, pencandu, homoseksual, pengangguran, dan perilaku politik yang radikal. Stigma yang dialami oleh ODHA, dapat digolongkan ke dalam jenis ini. Pandangan yang melekat mengenai ODHA adalah mereka menderita HIV AIDS karena perilaku yang menyimpang, padahal tidak selalu demikian.

Goffman juga mengungkapkan beberapa respons yang bisa diambil oleh orang-orang yang distigma dalam menghadapi orang-orang "normal" (tidak distigma atau menstigma). Khususnya mereka dengan stigma fisik, responsnya biasanya melalui kompensasi $^{8}$ atas kekurangan fisik mereka. Sedangkan mereka dengan stigma jenis lain, bisa membentuk kelompok-kelompok pendukung untuk membangun rasa kebersamaan dan saling memberi semangat.

Beberapa aturan berkomunikasi bagi orang-orang yang distigma dalam

\footnotetext{
${ }^{8}$ Kompensasi menurut KBBI Daring berarti pencarian kepuasan dalam suatu bidang untuk memperoleh keseimbangan dari kekecewaan dalam bidang lain
} 
menghadapi orang-orang "normal," juga diberikan oleh Goffman (Crossman 2016), antara lain:

- Seseorang harus mengasumsikan bahwa orang normal hanyalah tidak memiliki informasi memadai dan bukan pembenci.

- Tidak perlu merespons hinaan, dan orang yang distigma harus mengabaikan atau dengan sabar menyangkal serangan atau pandangan yang melatarbelakanginya.

- Orang-orang dengan stigma harus mencoba membantu mengurangi ketegangan dengan berbasa-basi dan menggunakan lelucon, atau bahkan "ejekan terhadap diri sendiri."

- Orang-orang dengan stigma harus memperlakukan orang-orang "normal" seakan-akan mereka mendapatkan kehormatan sebagai si bijaksana.

- Orang-orang dengan stigma harus membiarkan pertanyaan-pertanyaan yang mengganggu dan bersedia dibantu.

- Orang-orang dengan stigma harus menggunakan taktik "waktu jeda" dalam percakapan untuk pemulihan dari keterkejutan karena sesuatu yang mungkin diucapkan oleh orang lain.

- Orang-orang dengan stigma harus mengikuti etiket penyingkapan, misalnya dengan menggunakan ketidakmampuan sebagai topik dalam percakapan serius

- Seorang yang distigma harus melihat dirinya "normal" agar mudah menghadapi orang "normal."
Goffman mengatakan bahwa interaksi di antara orang-orang dengan stigma dan orang-orang tanpa stigma sejatinya penuh tekanan, karena mereka harus mengelola emosi-emosi yang kuat, pemikiran-pemikiran, dan tindakan-tindakan yang terikat pada stigma (Smith, 2009: 933).

Pendekatan interaksionisme simbolik berupaya menjelaskan hubungan di antara pemahaman, motif, dan rancangan pesan; serta terpenting menawarkan pemaknaan atas peran dan tindakan. Dengan perkataan lain, interaksionisme simbolik berusaha menjelaskan bagaimana orang-orang mengadaptasikan strategi komunikatif mereka dalam berbagai komunikasi tatap muka dengan berbagai macam orang lewat mekanisme pengambilan peran (role taking) atau pengambilan perspektif (perspective taking) (Mulyana, 2013: xviii).

Dasar pemikiran interaksionisme simbolik mengasumsikan realitas sosial sebagai proses dan masyarakat dilihat sebagai sebuah interaksi simbolik bagi individu-individu yang ada di dalamnya. Jadi esensi interaksi simbolik adalah aktivitas yang menjadi ciri khas manusia, yakni komunikasi atau pertukaran simbol yang diberi makna. Berikut ini adalah premis-premis di dalam interaksionisme simbolik, yaitu:

\section{Pentingnya makna bagi perilaku} manusia. Individu membentuk makna melalui proses komunikasi. Makna tidak bersifat intrinsik terhadap apapun, oleh karena itu dibutuhkan konstruksi interpretif diantara orang-orang untuk menciptakan makna. 
Riniwaty Makmur, Strategi Komunikasi Orang Dengan Hiv Aids (Odha) Menghadapi Stigma..

2. Pentingnya konsep diri. Konsep diri (self-concept) adalah seperangkat persepsi yang relatif stabil dan dipercaya orang mengenai diri seseorang.

3. Hubungan antara individu dan masyarakat. Tema ini berkaitan antara kebebasan individu dan batasan sosial. Dalam hal ini dicoba dijelaskan mengenai keteraturan dan perubahan dalam proses sosial (Mulyana, 2013: 71).

Bagi ODHA, interaksionisme simbolik memberikan kerangka pikir dalam interaksi dengan orang lain, dan menempatkan diri di dalam masyarakat. Bagaimana ODHA melihat dirinya atau konsep diri, akan menentukan pilihan strategi komunikatif mereka dalam komunikasi tatap muka. Konsep diri terbentuk dari interaksi dengan orang lain, sebagaimana dijelaskan di bagian berikutnya.

Konsep diri atau self- concept adalah cara kita melihat diri kita, yang langsung berdampak pada bagaimana seseorang berkomunikasi dan berhubungan dengan dunia sekitar. Seseorang dengan konsep diri positif, khususnya self-esteem, lebih mungkin tidak hanya berpikir baik tentang dirinya dan diterima oleh orang lain, tetapi juga merasa lebih nyaman dan melakukan lebih baik dalam situasi yang mendua. Aspek-aspek lain dari self-concept termasuk optimisme, kepribadian yang ekstrover, dan selfreliance (kemandirian), juga berkontribusi pada penguatan kemampuan berkomunikasi (Chen di dalam Encyclopedia of Communication
Theory 1, Editor Littlejohn \& Foss, 2009: 150).

Charles Horton Cooley memperkenalkan Looking Glass Theory tentang konsep diri. Dalam teori ini, kita seakan-akan meletakan cermin di depan kita, dan membayangkan bagaimana orang lain menilai penampilan kita, atau kemampuan kita untuk melihat diri kita sendiri dalam pantulan/ pandangan orang lain. Mead meminjam konsep cermin diri ini dalam teori interaksionisme simbolik. Bagi Mead, diri berkembang dari sebuah pengambilan peran yang khusus (role taking), yaitu: membayangkan bagaimana kita dilihat orang lain. Menurut Mead, konsep diri terbentuk atas dua unsur yang saling berhubungan yaitu "I" dan "Me". "I" adalah subjektivitas diri yang berasal dari dalam diri sendiri secara spontan. Sedangkan "Me" dibentuk berdasarkan objek yang terlihat dari looking-glass self yang merupakan hasil dari pengambilan peran orang lain dalam lingkungan sekitar. Kemampuan untuk merefleksikan diri kita sendiri berdasarkan perspektif orang lain (Griffin, 2012: 60).

Pendekatan dramaturgi dari Erving Goffman merupakan salah satu model pendekatan interaksionisme simbolik dari Mead (Mulyana, 2013: 110). Seperti diketahui Teori Interaksionisme Simbolik adalah bagaimana individu mengartikan dunia dan dirinya sendiri, dalam kaitan dengan masyarakatnya. Mead melihat pikiran (mind) dan diri (self) menjadi bagian dari perilaku manusia, yaitu interaksi dengan orang lain. Sementara 
itu melalui Teori Dramaturgi, Goffman memakai analogi drama dan teater untuk menjelaskan interaksi manusia. Teori ini sangat menarik karena melihat manusia sebagai aktor yang dapat memiliki "dua muka." Tidak hanya itu, Teori Goffman juga memiliki keluasan dalam aplikasinya karena sangat menyatu dengan kehidupan sehari-hari.

Goffman memberikan dasar teori mengenai bagaimana individu tampil di dunia sosial lewat karyanya yang berjudul The Presentation of Self in Everyday Life (1959) (Mulyana, 2013: 110). Ia menganggap individu sebagai satuan analisis. Goffman tidak tertarik pada struktur sosial, tetapi pada interaksi tatap muka atau kehadiran bersama (orang-orang berada pada tempat dan waktu yang sama/ copresence). Menggunakan metafor teater, Goffman membagi kehidupan sosial ke dalam dua panggung, yaitu:

1. Panggung depan (Front stage), yakni tempat atau peristiwa sosial yang memungkinkan individu menampilkan peran formal atau bergaya layaknya aktor yang berperan. Panggung depan merupakan wilayah yang ditonton khalayak.

2. Panggung belakang (Back stage), yakni tempat untuk mempersiapkan peran di panggung depan. Analogi dengan kamar rias pemain teater untuk mempersiapkan diri atau berlatih sebelum tampil di panggung depan (Mulyana, 2013: 114).

Berdasarkan dramaturgis, seseorang cenderung mengetengahkan sosok dirinya yang ideal sesuai dengan status peranannya dalam kegiatan rutinnya. Orang cenderung menyembunyikan fakta dan motif yang tidak sesuai dengan citra dirinya. Dramaturgi menjadi relevan untuk menjelaskan kemungkinankemungkinan perilaku ODHA dalam menghadapi stigma terhadap dirinya. Tentu saja perilaku ini tidak bisa dilepaskan dari konsep diri sebagaimana yang menjadi elemen dari teori interaksionisme simbolik.

\section{METODOLOGI PENELITIAN}

Penelitian ini merupakan penelitian kualitatif-deskriptif dengan metode studi kasus. Penelitian kualitatif adalah tradisi dalam ilmu pengetahuan sosial yang secara fundamental bergantung dari pengamatan pada manusia baik dalam kawasannya maupun dalam peristilahannya (Moleong, 2014: 4).

Pada penelitian studi kasus peneliti mengeksplorasi kehidupan nyata, sistem terbatas kontemporer (kasus) atau beragam sistem terbatas (berbagai kasus), melalui pengumpulan data yang detail dan mendalam yang melibatkan beragam sumber informasi atau sumber informasi majemuk seperti pengamatan, wawancara, dan dokumen berbagai laporan, dan melaporkan deskripsi kasus dan tema kasus (Creswell, 2013: 136).

Subjek penelitian pada studi kasus ini adalah ODHA, keluarga ODHA dan pihak-pihak lain yang terlibat dalam upaya pencegahan dan pengobatan AIDS seperti dokter, dan Yayasan pegiat HIV AIDS. Informan sebanyak 
Riniwaty Makmur, Strategi Komunikasi Orang Dengan Hiv Aids (Odha) Menghadapi Stigma..

enam orang dipilih dengan menggunakan teknik purposif dan berdasarkan kesediaan informan untuk berbagi. Nama informan dalam penelitian ini disamarkan untuk menjaga kerahasiaan dan privasi. Selain itu data juga diperoleh dari meneliti "percakapan" ODHA pada forum diskusi di situs Yayasan Spiritia ${ }^{9}$, serta dokumentasi lain seperti laporan lembaga resmi, dan berita media massa. Objek penelitian adalah stigma terhadap ODHA.

Creswell menggambarkan pengumpulan data sebagai rangkaian aktivitas yang saling terkait dan bertujuan untuk mengumpulkan informasi guna menjawab pertanyaanpertanyaan penelitian yang muncul (2014: 206). Dalam penelitian ini pengumpulan data dilakukan pada sumber data primer dan sekunder selama bulan Mei - Agustus 2016. Teknik pengumpulan data yang digunakan adalah:

- Wawancara tatap muka dan atau telepon/ email

- Dokumentasi

Penelitian ini menggunakan beragam sumber data atau menggunakan teknik triangulasi untuk mendukung validasi datanya. Menurut Creswell, ketika para peneliti kualitatif berusaha menemukan bukti untuk mendokumentasikan kode atau tema dalam beragam sumber data, mereka sebenarnya sedang mentriangulasi

\footnotetext{
${ }^{9}$ Yayasan Spiritia adalah LSM yang memfasilitasi kelompok dukungan sebaya bagi ODHA, memberikan layanan informasi dan komunikasi baik untuk ODHA dan masyarakat. Situsnya dapat dilihat pada alamat berikut: http://www.spiritia.or.id/index.php
}

informasi dan menyediakan validitas bagi temuan mereka. Triangulasi adalah salah satu strategi validasi penelitian kualitatif, yang mana para peneliti menggunakan beragam sumber, metode, peneliti, dan teori untuk menyediakan bukti penguat (Creswell 2014: 349).

\section{HASIL PENELITIAN DAN PEMBAHASAN}

Stigma terhadap ODHA dipicu oleh rendahnya pengetahuan dan pemahaman anggota masyarakat terhadap fakta-fakta mengenai HIV AIDS, dan informasi yang telah meluas bahwa HIV AIDS disebabkan oleh perilaku "menyimpang." Menurut Teori Struktural, deviant atau penyimpangan dipahami sebagai perilaku yang merupakan karakter berlawanan dengan norma-norma sosial (Bajari, 2008). Padahal tidak semua ODHA mendapatkan penyakitnya dari perilaku yang berisiko. Seorang ibu rumah tangga atau seorang anak-anak juga bisa terkena HIV AIDS.

Rendahnya pengetahuan mengenai HIV AIDS sebagai penyebab utama stigma, didukung oleh penelitianpenelitian sebelumnya (Butt et al., 2010; Harapan et al., 2013). Hal ini juga diungkapkan oleh seorang informan yang mendapatkan virus HIV dari suaminya. Sewaktu kejadian, mereka tinggal di rumah orang tua suaminya (mertua) bersama keluarga seorang saudara iparnya. Sementara mertuanya telah meninggal dunia. Setelah suaminya meninggal dunia, informan ini diminta iparnya untuk meninggalkan rumah, karena melihat dia memiliki 
sakit yang sama dengan almarhum suaminya. Berikut ini petikan dari wawancara dengan informan yang bersangkutan:

"Saat itu tidak ada pembicaraan mengenai apakah saya juga menderita HIV atau tidak, tetapi sepertinya ipar saya menduga saya HIV karena melihat gejala penyakit yang sama seperti suami saya. Waktu itu ipar saya sedang hamil, dan dia bilang khawatir penyakit saya menular ke janinnya."

Pemahaman yang kurang mengenai cara penularan HIV AIDS diceritakan oleh seorang informan ODHA yang juga menjadi aktivis untuk menjangkau dan mendampingi ODHA:

"Pernah ada yang menanyakan kepada saya, kok tidak takut bergaul dengan ODHA, karena dia beranggapan penularan bisa terjadi ketika kita makan bersama atau melalui keringat, yang sama sekali tidak benar."

Rasa takut tertular tetap ada meskipun seseorang telah memiliki pengetahuan mengenai HIV AIDS. Hal ini yang kadang-kadang mendorong stigma oleh keluarga inti, karena keluarga berada dalam kondisi yang selalu berdekatan dengan ODHA. Berikut ini adalah ungkapan seorang informan yang (mantan) suaminya menderita HIV AIDS.

"Saya mengerti bagaimana cara penularan HIV AIDS, tetapi saya tetap takut ketika mengetahui suami saya adalah ODHA.
Semuanya tidak semudah yang dikatakan orang-orang. Saya tahu, saya telah menstigma suami saya karena keadaannya. Akan tetapi, saya sangat menghawatirkan masa depan anak kami yang masih kecil. Kalau saya juga tertular, siapa yang akan mengurusi anak kami? Saya mencoba ikut kelompok pendukung, tetapi bukannya dikuatkan, saya malah semakin terintimidasi oleh keadaan kami. Tambahan lagi, rasanya suami saya seperti tidak mau mengerti, dia tetap menuntut untuk dilayani. Saya tahu agama mengajarkan saya untuk taat pada keinginan suami, seperti untuk berhubungan... tetapi saya tidak bisa. Saya takut."

Di sisi lain, ada juga ODHA yang menemukan pasangan yang mengerti keadaannya. Seorang informan ODHA menceritakan kebahagiaannya menemukan pasangan hidup yang mau menerima dirinya apa adanya termasuk kenyataan bahwa dia adalah ODHA. Saat ini informan itu telah menikah dengan pasangannya yang "normal" selama bertahun-tahun. Stigma dari keluarga dekat sepertinya sangat bergantung pada situasi setiap individu dan lingkungan tempat dia berada. Penelitian juga menemukan seorang informan yang membuka diri hanya kepada keluarga terdekatnya yaitu ibu dan saudaranya, tetapi merahasiakan kondisinya terhadap orang lain.

Namun demikian, seluruh informan mengungkapkan pernah mengalami stigma dan bahkan diskriminasi, termasuk oleh petugas medis. Studi yang dilakukan oleh 
Riniwaty Makmur, Strategi Komunikasi Orang Dengan Hiv Aids (Odha) Menghadapi Stigma..

Harapan et al., tahun 2013 di Banda Aceh mendapati perlakuan stigma yang umum di kalangan petugas kesehatan (dokter, perawat dan mahasiswa kedokteran) terhadap ODHA, dan ini juga mirip dengan temuan-temuan penelitian di luar negeri. Rumah sakit paling banyak disebutkan sebagai tempat terjadinya stigma. ODHA menilai stigma terhadap mereka salah satunya dari komunikasi non verbal seperti ekspresi wajah perawat, cara perawat memegang dirinya ketika melakukan pemeriksaan yang hanya menggunakan dua jari, dan melihat perawat memakai sarung tangan hingga dua lapis sebelum melakukan pemeriksaan pada dirinya ${ }^{10}$.

Agama atau sikap religius ternyata berhubungan dengan sikap yang menstigma. Seorang informan mengungkapkan bahwa dia pernah mendapatkan kata-kata yang tidak menyenangkan dari pemuka agamanya. $\mathrm{Si}$ pemuka agama itu mengatakan kepada orang tuanya, agar menyingkirkan dia dan anak-anaknya dari rumah si orang tua. Sebuah studi lain juga memperlihatkan bahwa agama memengaruhi sikap-sikap diskriminasi, dan derajatnya meningkat dengan derajat penting agama bagi orang yang bersangkutan (Harapan et al., 2013). Literatur umum menyatakan bahwa petugas kesehatan yang lebih religius cenderung lebih menstigma terhadap ODHA yang dianggap telah tertular

\footnotetext{
${ }^{10}$ Percakapan/ diskusi sesama ODHA di halaman Forum pada situs Yayasan Spiritia pada alamat:

http://spiritia.or.id/smf/index.php?topic=129.ms g1932\#msg1932
}

virus HIV AIDS karena praktik-praktik yang kurang bermoral. Pengalaman dan status moral memang telah menjadi bagian dari stigma dalam perspektif antropologi (Kleinman dan HallClifford, 2009: 3).

Penolakan oleh sekolah seperti pernah diekspos di media massa, ternyata juga dialami oleh beberapa orang tua ODHA. Sekolah berdalih bisa memahami bahwa penularan HIV tidak mudah, tetapi banyak pihak lain yang mungkin tidak mengerti/ menerima, seperti staf sekolah, orang tua murid, dan sebagainya. Tidak semua kasus penolakan oleh sekolah ini mendapatkan liputan media massa seperti kasus putri dari Fajar, seorang ODHA yang tadinya telah diterima di sebuah sekolah swasta, tetapi kemudian ditolak ketika sekolah mengetahui bahwa orangtuanya terdampak HIV AIDS $^{11}$.

Menurut seorang informan, kebanyakan orang tua yang ODHA, ketika mengalami penolakan memilih mengalah dan mencari sekolah lain. Mereka maklum akan stigma dari masyarakat, dan memilih bersabar. Hal ini selaras dengan aturan komunikasi Gofman, yaitu tidak perlu merespons hinaan, dan orang yang distigma harus mengabaikan atau dengan sabar menyangkal serangan atau pandangan yang melatarbelakanginya (Crossman 2016).

11

http://www.bbc.com/indonesia/berita_indonesia/2011/12 /111205_aidsdonbosco.shtml 
Sementara itu di tempat kerja, pegawai "dilindungi" dengan Keputusan Menteri Ketenagakerjaan dan Transmigrasi, Kepmen No. 68/MEN/ IV/2004 tentang pencegahan dan penanggulangan HIV/AIDS di tempat Kerja. Kepmen ini melarang diskriminasi terhadap orang-orang yang terinfeksi HIV/AIDS, termasuk melarang perusahaan melakukan tes HIV AIDS terhadap calon karyawan/ buruh. Menurut informan dari sebuah yayasan pegiat HIV AIDS, kebanyakan perusahaan telah menjalankan Kepmen tersebut dalam hal tidak menanyai calon karyawn mengenai status HIV mereka. Akan tetapi perusahaan-perusahaan masih sulit diajak bekerjasama dalam memberikan layanan pemeriksaan dan konsultasi HIV bagi karyawan. "Komitmen dari pimpinan tertinggi perusahaan susah diperoleh, sementara itu karyawan juga enggan mengikuti pemeriksan dan konseling dengan alasan takut stigma karena kerahasiaan sulit dijamin, walaupun mereka mungkin termasuk kelompok berisiko," ujar informan. Dalam hal ini perusahaan-perusahaan internasional dianggap yang paling bisa terbuka dan bersikap mendukung terhadap langkahlangkah preventif dan kuratif HIV.

Berbagai pihak yang berpotensi melakukan stigma pada ODHA sebagaimana hasil penelitian diilustrasikan pada gambar 1:

\section{Gambar 1.}

\section{ODHA dan Kemungkinan Pelaku Stigma}

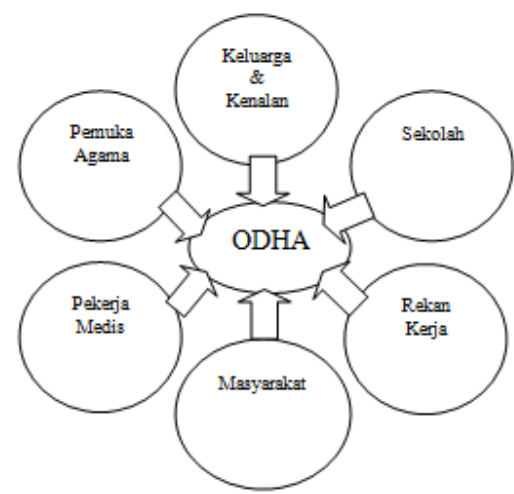

Sumber: Wawancara dan telaah dokumen

$\begin{array}{lll}\text { Strategi } & \text { ODHA dalam } & \text { belum memiliki pemahaman yang benar } \\ \text { menghadapi stigma dan atau } & \text { tentang HIV AIDS. Sebagaimana } \\ \text { diskriminasi secara umum ada dua. } & \text { diasumsikan oleh teori interaksionisme } \\ \text { Pertama, ODHA berusaha "menutupi" } & \text { simbolik, di dalam masyarakat terdapat } \\ \text { status HIV AIDS-nya di depan umum. } & \text { norma-norma sosial yang membatasi } \\ \text { Pemilihan strategi ini disebabkan } & \text { perilaku. Orang dan kelompok } \\ \text { ODHA menyadari sebagian masyarakat } & \text { dipengaruhi oleh proses budaya dan }\end{array}$


Riniwaty Makmur, Strategi Komunikasi Orang Dengan Hiv Aids (Odha) Menghadapi Stigma..

sosial (Mulyana, 2013: 71). Kendati terdampak HIV AIDS bukan karena perilaku "menyimpang," strategi ini sepertinya menjadi pilihan kebanyakan ODHA dalam menjalani dunia kesehariannya. Salah seorang informan ODHA mengungkapkan bahwa dia hanya memberitahukan keadaannya kepada ibu dan seorang kakaknya. Selain itu tidak ada lagi yang tahu, termasuk anak-anaknya. Hal ini dilakukannya untuk menjaga agar jangan sampai dirinya, keluarga atau bahkan keluarga besarnya mengalami stigma. Berikut ini petikan dari pengalaman informan:

"Saya sendiri lebih memilih cara menyembunyikan status saya sambil turut membantu penanggulangan HIV, supaya jangan sampai ada korban karena HIV, tanpa menunjukan kalau saya juga penderita HIV....."

Strategi ini menempatkan pelakunya pada posisi mendua (dua muka). Dia secara harafiah memainkan dua peran: panggung depan di mana status HIV AIDS “disembunyikan," dan panggung belakang dengan kenyataan bahwa dia adalah ODHA, seperti teori dramaturgi Goffman. Untuk menjaga kerahasiaan statusnya dari lingkungan tempat tinggalnya, seorang informan memilih melakukan pengobatan ARV (antiretroviral) di luar kota. Jadi sebulan sekali, dia harus melakukan perjalanan sekitar 3-4 jam bahkan lebih karena kemacetan lalu lintas, untuk melakukan pemeriksaan kesehatan sekaligus menebus obat. Cara yang sama juga dilakukan ODHA lain yang bekerja di sebuah pabrik di pinggiran Jakarta. ODHA ini setiap seminggu sekali, mengambil obat di salah satu rumah sakit di Jakarta.

Apa yang dilakukan ODHA ODHA di atas, merupakan praktik dari teori dramaturgi. Di panggung depan di hadapan anak-anak, keluarga dan anggota masyarakat di tempat domisilinya, serta di tempat kerja, mereka memainkan peran bukan sebagai ODHA. Baru ketika harus memeriksakan kesehatan dan mengambil obat ARV, mereka menampilkan jati diri sebenarnya sebagai ODHA. Akan tetapi di panggung belakang ini, mereka tidak bisa menghindari kehadiran penonton, meski terbatas pada petugas medis.

Strategi kedua adalah milik orangorang yang percaya diri, pasrah atau orang-orang dengan dukungan yang solid, yaitu berterus terang tentang keadaannya. Bisa juga dikatakan orangorang ini mungkin memiliki konsep diri positif, atau telah berserah diri (pasrah) seperti pengakuan seorang informan. Dukungan dari keluarga inti dan orang dekat menjadi kata kunci yang menentukan. Seorang ODHA mengungkapkan pengalamannya sebagai berikut:

"Saya termasuk yang terbuka dengan keluarga, beberapa teman kantor, beberapa teman dekat, dan pacar... mereka malah memberikan dukungan luar biasa, dan tidak ada yang diskriminasi. $" 12$

\footnotetext{
${ }^{12}$ Op.Cit.
} 
Tidak semua ODHA "beruntung" mendapatkan dukungan keluarga dan orang dekat, atau lingkungan kerja yang kondusif. Itulah sebabnya, "dukungan kelompok sebaya" sebuah gerakan kelompok dukungan bagi ODHA dibentuk untuk saling menguatkan. Hal ini selaras dengan respons yang disarankan oleh Goffman bagi mereka yang distigma, agar membentuk kelompok-kelompok pendukung untuk membangun rasa kebersamaan dan saling memberikan semangat (Crossman, 2016).

Berterus terang bukan pilihan yang mudah bagi ODHA. Konsep diri yang positif agar bisa melihat pantulan dirinya (looking- glass self) yang juga positif berperan penting. Kesadaran akan mendapatkan perlakuan yang tidak menyenangkan karena stigma, merupakan hal yang menakutkan. Stigma itu juga tidak terbatas pada pribadi si ODHA, tetapi berpotensi menimpa keluarga dekatnya seperti dikhawatirkan seorang informan. Menurut informan dokter dan ketua sebuah yayasan yang berusaha menjangkau orang-orang berisiko maupun yang telah terjangkit HIV, tidak sedikit ODHA yang tidak mau berobat ARV karena takut distigma. Tidak sedikit pula orang berisiko yang tidak mau memeriksakan diri (meskipun gratis), karena ketakutan akan stigma ini.

Di sisi lain, keterbukaan ini mendapatkan kritik juga dari beberapa ODHA. Menurut mereka, ODHA juga harus bijak dalam membuka diri, dan kepada siapa membuka diri. Diperlukan evaluasi mengenai orang/ kelompok yang diajak berkomunikasi. Ada baiknya sebelum berterus terang, ODHA memberikan dulu pengetahuan dan pemahaman mengenai HIV AIDS kepada orang yang diajak berkomunikasi. Dengan perkataan lain, ODHA perlu memahami konsep diri dan perspektif orang lain sebelum berkomunikasi. Diperlukan kemampuan untuk merefleksikan diri berdasarkan perspektif orang lain (role taking), atau membayangkan bagaimana orang lain menilai kita, atau kemampuan kita untuk melihat diri kita sendiri dalam pantulan/ pandangan orang lain (Looking Glass Theory). Tanpa ini, ODHA bisa dianggap bertanggung jawab terhadap stigma bagi dirinya, ketika dia secara tidak tepat membuka diri pada orang/ kelompok tertentu. Seorang informan mengungkapkan:

"Masyarakat tidak paham, tetapi juga ada masalah penyampaian. Sebaiknya sebelum menyampaikan bahwa kita menderita HIV, pastikan penerima pesan paham dulu apa itu HIV AIDS. Jadi kadangkadang stigma dan diskriminasi itu timbul karena diri kita sendiri bukan karena orang lain. Kita harus peka, berikan pemahaman dulu, setelah itu kita bisa menilai apakah mereka bisa menerima atau tidak."

Terlepas dari pilihan untuk terbuka atau tertutup, kebanyakan ODHA berusaha bersikap layaknya orang normal dalam menjalani kehidupannya sehari-hari. Hal ini 
Riniwaty Makmur, Strategi Komunikasi Orang Dengan Hiv Aids (Odha) Menghadapi Stigma..

senada dengan strategi yang disarankan oleh Goffman, yakni seorang yang distigma harus melihat dirinya "normal" agar mudah menghadapi orang "normal" (Crossman 2016). Strategi menghadapi stigma dirangkum pada gambar 2 .

Gambar 2.

\section{Strategi Menghadapi Stigma}

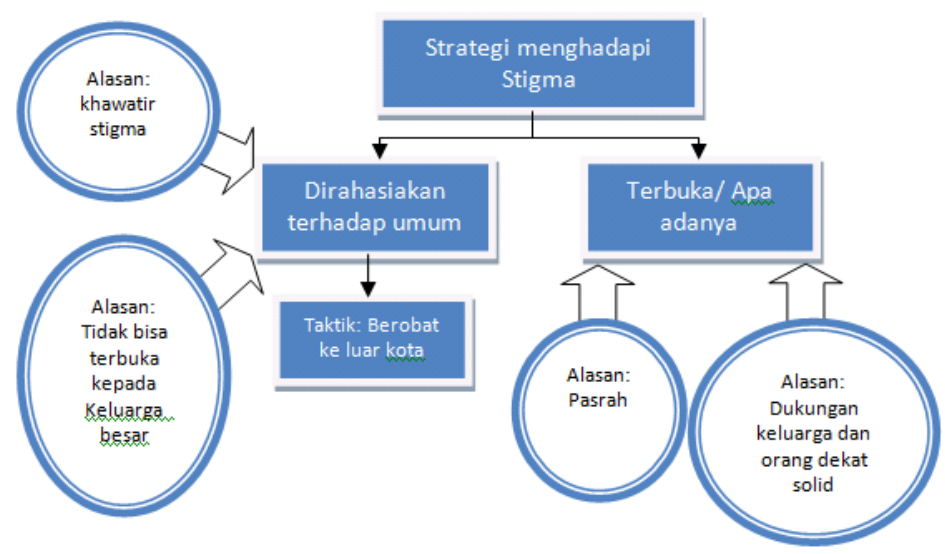

Sumber: modifikasi peneliti

\section{KESIMPULAN}

Stigma terhadap ODHA umum terjadi di masyarakat dan dilakukan oleh berbagai pihak, seperti keluarga, rekan kerja, petugas medis, sekolah, dan pemuka agama, disebabkan kesadaran/ pengetahuan yang kurang/ tidak tepat mengenai HIV AIDS dan rasa takut/ khawatir. Penstigmaan ditunjukan baik melalui komunikasi verbal yaitu penolakan langsung dan komunikasi non verbal seperti ekspresi wajah dan bahasa tubuh. Akibat takut distigma, banyak orang tidak bersedia mengikuti tes VCT. Sementara orang-orang yang telah diidentifikasi sebagai ODHA, tidak melakukan pengobatan ARV yang krusial untuk menekan perkembangan virus HIV di dalam tubuhnya, karena juga takut distigma.
Stigma dari keluarga dekat bersifat bergantung pada situasi individu ODHA dan lingkungannya. Keberadaan anak sering menjadi faktor utama dalam menyikapi ODHA. Pertimbangan bagi keluarga inti untuk hidup bersama ODHA lebih berat, karena terdapat kedekatan secara emosi dan fisik yang melebihi orang-orang lain.

Dalam menghadapi stigma terhadap penyakitnya, ODHA melakukan salah satu dari dua strategi, yaitu pertama tidak berterus terang mengenai status HIV AIDS-nya, dan kedua berterus terang/ apa adanya. Selain pertimbangan tentang diri pribadi dalam pengambilan strategi, ODHA juga memikirkan keluarga inti dan keluarga besarnya yang juga bisa terdampak penstigmaan. Oleh karena itu dukungan khususnya dari keluarga dan 
orang terdekat serta lingkungan kerja, konsep diri yang positif, serta kepasrahan/ penerimaan menjadi faktorfaktor yang sangat penting dalam kehidupan ODHA dan penentuan strategi mereka.

ODHA juga "dituntut" oleh sesama ODHA untuk bisa bijak dalam membuka diri kepada lingkungannya, karena bisa saja pihak yang diberi informasi mengenai keadaan si ODHA tidak memiliki pengetahuan memadai mengenai HIV AIDS, sehingga alih-alih memahami malah menstigma.

\section{DAFTAR PUSTAKA}

Bajari, Atwar. (2008). Konspirasi Masyarakat dalam Membentuk Stigma Individu Telaah Teori Penjulukan (Labelling Theory) dari Howard Becker. Diunduh dari

https://atwarbajari.wordpress.com /

Butt, Leslie et al., (2010). Stigma and HIV AIDS in Highlands Papua. Pusat Studi KependudukanUNCEN, Abepura, Papua dan University of Victoria, Canada

Chen, Guo-Ming. (2009). Competence Theories di dalam Encyclopedia of Communication Theory 1 (Editor: Stephen W. Littlejohn \& Karen A. Foss). Sage.

Creswell, John W. (2014). Penelitian Kualitatif \& Desain Riset Memilih di Antara Lima

Pendekatan. Alihbahasa Ahmad Lintang Lazuardi. Pustaka Pelajar.

Crossman, Ashley. (2016). Stigma: Notes on the Management of Spoiled Identity.
Diunduh dari http://sociology.about.com/od/Wo rks/a/Stigma-Notes-On-TheManagement-Of-SpoiledIdentity.htm

Grifin, Em. (2012). A First look at Communication Theory. Eight Edition. McGraw Hill.

Harapan et al. (2013). HIV-related stigma and discrimination: a study of health care workers in Banda Aceh, Indonesia. HIV stigmatization and discrimination Vol. 22, No. 1, February 2013

Hermawati, Pian. (2011). Hubungan Persepsi ODHA terhadap Stigma HIV AIDS Masyarakat dengan Interaksi Sosial pada ODHA. Skripsi Fakultas Psikologi UIN Syarif Hidayatullah Jakarta.

Infodatin (Pusat Data dan Informasi Kementerian Kesehatan RI). (2014). Situasi dan analisis HIV AIDS.

Kleinmann, Arthur dan Hall-Clifford, Rachel. (2009). Stigma: A social, cultural,

and moral process. Journal of Epidemiology and Community Health 2009;63:6418-419 doi:10.1136/jech.2008.084277

Mulyana, Deddy. (2013). Metodologi Penelitian Kualitatif. Bandung: PT Remaja Rosdakarya

Moleong, Lexi J. (2014). Metode Penelitian Kualitatif. Bandung: PT Remaja Rosdakarya.

Sasodoro et al. (2009). Hubungan Pengetahuan tentang HIV AIDS dengan Stigma Orang dengan 
Riniwaty Makmur, Strategi Komunikasi Orang Dengan Hiv Aids (Odha) Menghadapi Stigma..

HIV AIDS di Kalangan Pelajar SMA. Berita Kedokteran Masyarakat, Vol. 25, No. 4, Desember 2009

Smith, Rachel A. (2009). Stigma Communication di dalam
Encyclopedia of Communication Theory 2 (Editor: Stephen W. Littlejohn \& Karen A. Foss). Sage.

UNAIDS. (2016). Global AIDS Update. 